\title{
Optimization of immobilized Lactobacillus pentosus cell fermentation for lactic acid production
}

\author{
Jianfei Wang ${ }^{1}$, Jiaqi Huang ${ }^{1,2}$, Hannah Laffend ${ }^{1}$, Shaoming Jiang ${ }^{1}$, Jing Zhang ${ }^{1}$, Yuchen Ning ${ }^{1}$, Mudannan Fang \\ and Shijie Liu ${ }^{1 *}$
}

\begin{abstract}
Parametric optimization is an effective way in fermentation process to improve product yield and productivity in order to save time, space and financial resources. In this study, Box-Behnken design was applied to optimize the conditions for lactic acid production by immobilized Lactobacillus pentosus ATCC 8041 cell fermentation. Two quadratic models and response surface methodology were performed to illustrate the effect of each parameters and their interactions on the lactic acid yield and glucose consumption rate in immobilized L. pentosus ATCC 8041 cell fermentation. The maximum lactic acid yield was obtained as $0.938 \pm 0.003 \mathrm{~g} / \mathrm{g}$ glucose with a productivity of $2.213 \pm 0.008 \mathrm{~g} /$ $(\mathrm{L} \times \mathrm{h})$ under the optimized conditions of $2.0 \mathrm{~mm}$ bead diameter, $5.60 \mathrm{pH}, 115.3 \mathrm{~g} / \mathrm{L}$ initial glucose concentration, and $398.2 \mathrm{mg}$ biomass (CDW) in $100 \mathrm{~mL}$ hydrogel. The analysis of variance indicated that the quadratic model was significant and could be used to scale up the fermentation process.
\end{abstract}

Keywords: Lactobacillus pentosus, Immobilization, Lactic acid, Optimization

\section{Introduction}

Lactic acid (LA) is a hygroscopic non-toxic organic compound that has been widely utilized in the cosmetic, pharmaceutical, food, and chemical industries (Vijayakumar et al. 2008). In recent years, polylactic acid (PLA) polymerized from LA has received widespread attention for its excellent biocompatibility and bioabsorbability (Abdel-Rahman et al. 2011). PLA has a wide range of applications with the benefits of environmental protection and energy saving, which can be considered as a suitable alternative for traditional plastics produced by the petrochemical industry (Laopaiboon et al. 2010). Therefore, the market demand for LA has gradually increased (Okano et al. 2010).

Chemical synthesis and fermentation are the main methods of industrial production of LA (Abdel-Rahman

\footnotetext{
*Correspondence: sliu@esf.edu

${ }^{1}$ Department of Paper and Bioprocess Engineering, SUNY College of Environmental Science and Forestry, Syracuse, NY 13210, USA Full list of author information is available at the end of the article
}

et al. 2011). The racemic mixture (DL-LA) will be formed during LA production process by chemical synthesis method, resulting in an increase in its cost of separation and purification. In addition, the chemical synthesis method still has the problem of high energy consumption. Nowadays, the production of compounds based on microbial conversion has become an important research direction. Optically pure LA (D-LA or L-LA) can be produced by fermentation method according to specific LA bacteria (LAB), leading to a decrease in time period and cost of recycle process (Bahry et al. 2019). Moreover, the fermentation conditions for LA production are milder, which is regarded to be an environment-friendly production method (Zhao et al. 2016).

Immobilized cell fermentation has attracted great attention in the fields of scientific research and industry. Compared with free cell fermentation, immobilized cell fermentation has many advantages, such as higher cell density in the fermenter, higher yield and production rate during fermentation process, high

\section{Springer Open}

(c) The Author(s) 2020. This article is licensed under a Creative Commons Attribution 4.0 International License, which permits use, sharing, adaptation, distribution and reproduction in any medium or format, as long as you give appropriate credit to the original author(s) and the source, provide a link to the Creative Commons licence, and indicate if changes were made. The images or other third party material in this article are included in the article's Creative Commons licence, unless indicated otherwise in a credit line to the material. If material is not included in the article's Creative Commons licence and your intended use is not permitted by statutory regulation or exceeds the permitted use, you will need to obtain permission directly from the copyright holder. To view a copy of this licence, visit http://creativecommons.org/licenses/by/4.0/. 
biological activity maintained for a long fermentation period, and the convenience of product recovery (Kumar et al. 2014; Dishisha et al. 2012; Ghorbani et al. 2011; Goranov et al. 2013). In addition, immobilized cells with excellent reusability can be easily separated from the fermentation medium, so they can be used in repeated batch fermentations to reduce the time and cost of cell culture (Djukić-Vuković et al. 2013). Sodium alginate (SA) is a common material to prepare immobilized cell bead based on a cross-linking reaction with $\mathrm{Ca}^{2+}$, while polyvinyl alcohol (PVA) can also be used to encapsulate cells due to its cross-linking reaction with borate ions (Lee and Mooney 2012; Tang et al. 2017). It has been reported that SA-PVA hydrogel for cell encapsulation has significant advantages over cell immobilization using a single material. PVA effectively improves the stability of immobilized cell beads with a promoted mechanical strength, while SA improves the surface properties of immobilized cell beads to keep from the tendency to agglomeration. Therefore, SA-PVA hydrogel can be regarded as a proper material for cell immobilization (Zhan et al. 2013).

Lactobacillus pentosus (L. pentosus) is a proper LAB to produce LA by consuming hexose via the EmbdenMeyerhof-Parnas (EMP) pathway. When glucose is absent, its metabolic pathway changes from homologous fermentation to heterologous fermentation, which produces LA via phosphoketolase (PK) pathway (Martinez et al. 2013). Both pathways are shown as following equations:

$$
\begin{aligned}
& \mathrm{C}_{6} \mathrm{H}_{12} \mathrm{O}_{6}+2 \mathrm{ADP}+2 \mathrm{Pi} \rightarrow 2 \mathrm{C}_{3} \mathrm{H}_{6} \mathrm{O}_{3}+2 \mathrm{ATP} \\
& \mathrm{C}_{6} \mathrm{H}_{12} \mathrm{O}_{6}+2 \mathrm{ADP}+2 \mathrm{Pi} \rightarrow \mathrm{C}_{3} \mathrm{H}_{6} \mathrm{O}_{3} \\
& \quad+\mathrm{CO}_{2}+\mathrm{C}_{2} \mathrm{H}_{5} \mathrm{OH}+2 \mathrm{ATP} .
\end{aligned}
$$

In this study, the aerobic fermentation of immobilized L. pentosus cells utilizing glucose is still homologous fermentation with no ethanol production, which has been confirmed based on NMR spectroscopy in our previous research.

Currently, few research efforts are found on immobilized L. pentosus cell fermentation. Our previous research focus on the effects of the concentration of carrier solutions and cross-linking agent solutions on the efficiency of immobilized L. pentosus cell fermentation, but further research is needed on other conditions of immobilization and fermentation. At the same time, proper design of experiment (DOE) is necessary for effective optimization of the conditions of immobilization and fermentation. Plackett-Burman design, Taguchi design, central composite design, and
Box-Behnken design are applied in most studies for optimization, while Doehlert design and superlative box design have also been used in researches to obtain a credible result (Huang et al. 2019; Wahla et al. 2019; Al-Gheethi et al. 2019; Sahin 2019; Chollom et al. 2019).

In this study, Box-Behnken design was used to optimize the bead diameter, $\mathrm{pH}$, initial glucose concentration, and the weight of biomass for immobilized $L$. pentosus ATCC 8041 cell fermentation. The effects of these parameters on the efficiency of immobilized L. pentosus ATCC 8041 cell fermentation were discussed based on the response surface and regression model.

\section{Materials and methods}

\section{Preliminary experiment}

Based on Plackett-Burman design, nine significant factors have been found in the fermentation of immobilized Lactobacillus pentosus cells by our preliminary experiment as shown in Table 1. The effects of the concentrations of two carrier solutions (SA and PVA) and two cross-linking agent solutions $\left(\mathrm{CaCl}_{2}\right.$ and $\left.\mathrm{H}_{3} \mathrm{BO}_{3}\right)$ on the fermentation performance of immobilized Lactobacillus pentosus cells have been reported in our previous study, and the effect of temperature has also been investigated. The influences of the remaining four factors will be discussed in this study.

\section{Seed culture preparation}

Lactobacillus pentosus ATCC 8041 was purchased from the American Type Culture Collection (ATCC), and stored in a refrigerator at $-8{ }^{\circ} \mathrm{C}$. The lyophilized cells were activated in de Man, Rogosa and Sharpe (MRS) medium at $37^{\circ} \mathrm{C}$ and $150 \mathrm{rpm}$ for $8 \mathrm{~h}$ on a rotary shaker (GYROMAXTM 747R, Amerex Instruments, Lafayette, CA, USA) before immobilization.

Table 1 Significant factors in the fermentation of immobilized Lactobacillus pentosus ATCC 8041 cells

\begin{tabular}{ll}
\hline Significant factor & Unit \\
\hline Concentration of SA & $\mathrm{g} / \mathrm{L}$ \\
Concentration of PVA & $\mathrm{g} / \mathrm{L}$ \\
Concentration of $\mathrm{CaCl}_{2}$ & $\mathrm{~g} / \mathrm{L}$ \\
Concentration of $\mathrm{H}_{3} \mathrm{BO}_{3}$ & $\mathrm{~g} / \mathrm{L}$ \\
Temperature & ${ }^{\circ} \mathrm{C}$ \\
Bead diameter & $\mathrm{mm}$ \\
$\mathrm{pH}$ & \\
Initial glucose concentration & $\mathrm{g} / \mathrm{L}$ \\
Biomass (CDW) & $\mathrm{mg}$ \\
\hline
\end{tabular}




\section{Design of experiment}

Box-Behnken design was used to optimize four parameters with three levels. As shown in Table 2, the four factors are bead diameter $\left(D_{\mathrm{B}}\right), \mathrm{pH}$, initial glucose concentration $\left(C_{\mathrm{G}}\right)$, and biomass $\left(B_{\mathrm{W}}, \mathrm{CDW}\right)$; respectively. Their levels from low to high were coded as $-1,0$, and +1 , respectively.

\section{Cell immobilization}

SA and PVA were gradually added to deionized water and dissolved with continuous agitation at $30{ }^{\circ} \mathrm{C}$ and $80{ }^{\circ} \mathrm{C}$, respectively, and subsequently mixed to prepare SA-PVA hydrogel. The concentration of SA and PVA in mixed solution was $2.0 \%$ and $6.0 \%$, respectively (Wang et al. 2020). A specific amount of L. pentosus ATCC 8041 cells were inject into $100 \mathrm{~mL}$ sterilized SA-PVA hydrogel solution with continuous agitation. The fully mixed SA-PVA hydrogel solution containing L. pentosus ATCC 8041 cells were injected into the mixed cross-linking agent solution consisting of $0.10 \mathrm{M} \mathrm{CaCl}_{2}$ and $2.5 \%$ $\mathrm{H}_{3} \mathrm{BO}_{3}$ by an electrostatic droplet generator (Wang et al. 2020; Poncelet et al. 1999). Immobilized cell beads with the certain diameter were prepared with the diameter error of $\pm 0.3 \mathrm{~mm}$. The prepared immobilized L. pentosus ATCC 8041 cell beads with a shape of approximate sphere were maintained in mixed cross-linking solution and stored in refrigerator at $4{ }^{\circ} \mathrm{C}$ for $4 \mathrm{~h}$, and subsequently washed by sterilized deionized water to remove residual $\mathrm{CaCl}_{2}$ and $\mathrm{H}_{3} \mathrm{BO}_{3}$ (Bahry et al. 2019; Zhu et al. 2009).

\section{Batch fermentation}

Batch fermentation was carried out in a 1.0-L New Brunswick Bioreactor (BIOFLO 110; New Brunswick Scientific Co., Edison, NJ, USA) with the working volume of $800 \mathrm{~mL}$ for $48 \mathrm{~h}$. Impellers of the bioreactor were disassembled to keep from the breakage of beads. Agitation speed was maintained at $150 \mathrm{rpm}$ by a magnetic stirrer. Fermentation medium prepared under optimum conditions of $5 \mathrm{~g} / \mathrm{L}$ peptone, $5 \mathrm{~g} / \mathrm{L}$ yeast extract, $0.5 \mathrm{~g} / \mathrm{L}$ $\mathrm{MgSO}_{4}$, and $0.5 \mathrm{~g} / \mathrm{L} \mathrm{KH}_{2} \mathrm{PO}_{4}$ and glucose with specific concentration were prepared and sterilized (Lee et al. 2011). The fermentation $\mathrm{pH}$ was controlled at designed value by adding $5 \mathrm{~mol} / \mathrm{L} \mathrm{NaOH}$, and the fermentation temperature was maintained at $35^{\circ} \mathrm{C}$ by a heat blanket.

\section{Chemical analysis}

The concentrations of glucose and LA were measured by proton nuclear magnetic resonance spectroscopy $\left({ }^{1} \mathrm{H}\right.$ NMR). NMR samples consisting of $0.5 \mathrm{~mL}$ fermentation sample, $0.4 \mathrm{~mL}$ deuterium oxide (Acros organics), and $0.1 \mathrm{~mL}$ internal standard were prepared in $5-\mathrm{mm}$ o.d. nuclear magnetic resonance (NMR) tubes (Corning, NY, USA) for ${ }^{1} \mathrm{H}$ NMR analysis (Holzgrabe 2010). The internal standard contained $95.5 \mathrm{wt} \%$ deuterium oxide, $4.2 \mathrm{wt} \%$ glucosamine, $0.2 \mathrm{wt} \%$ trimethylamine and $0.1 \mathrm{wt} \%$ trimethylsilyl propionate. The signal peak area of $\alpha$-glucose $(\mathrm{C} 1-\mathrm{H}), \beta$-glucose $(\mathrm{C} 1-\mathrm{H})$, and LA $(\mathrm{C} 3-\mathrm{H})$ was integrated by using MestReNova software on ${ }^{1} \mathrm{H}$ NMR spectrum at $5.25 \mathrm{ppm}, 4.65 \mathrm{ppm}$ and $1.35 \mathrm{ppm}$ (Mittal et al. 2009; Buyondo and Liu 2013). The calibration curve was developed by the linear relationship between the concentration and peak area for the calculation of glucose concentration and LA concentration.

\section{Statistical analysis}

All the experimental values are shown in Table 3 as the format "mean value \pm standard deviation". The analysis of variance (ANOVA) was carried out by Design Expert (Version 11). The response surface was applied to describe the effects of different factors on the efficiency of immobilized L. pentosus ATCC 8041 cell fermentation.

Quadratic models of LA yield and LA productivity were generated to show the functional relationship between factors and responses (Aslan and Cebeci 2007). For Box-Behnken design, a proper quadratic model will be established to show the effect of each factor and their quadratic interaction, which is shown as following format:

$$
Y=a_{0}+\sum_{i=1}^{n} a_{i} x_{i}+\sum_{i=1}^{n} a_{i i} x_{i}^{2}+\sum_{i=1}^{n} \sum_{j=1}^{n} a_{i j} x_{i} x_{j}+\varepsilon,
$$

where $Y, a_{0}, a_{i}, a_{i i}, a_{i j}, x_{i}$, and $x_{j}$ represent predicted responses, offset constant, linear term coefficient, square

Table 2 Range of factors for LA production by immobilized L. pentosus ATCC 8041 cells

\begin{tabular}{lllrrr}
\hline Factor & Parameter & Coded value & Unit & \multicolumn{2}{c}{ Level } \\
\cline { 3 - 6 } & & & $-\mathbf{1}$ & $\mathbf{0}$ \\
\hline 1 & Bead diameter & $D_{B}$ & $\mathrm{~mm}$ & 2 & 3 \\
2 & $\mathrm{pH}$ & & & 5 & 6 \\
3 & Initial glucose concentration & $C_{G}$ & $\mathrm{~g} / \mathrm{L}$ & 100 & 7 \\
4 & Biomass (CDW) & $B_{W}$ & $\mathrm{mg}$ & 200 & 300 \\
\hline
\end{tabular}


Table 3 Experimental data of LA production by immobilized L. pentosus ATCC 8041 cells

\begin{tabular}{|c|c|c|c|c|c|c|}
\hline \multirow[t]{2}{*}{ Run } & \multicolumn{4}{|l|}{ Factor } & \multicolumn{2}{|l|}{ Response } \\
\hline & $\begin{array}{l}\text { Bead diameter } \\
D_{B}(\mathrm{~mm})\end{array}$ & $\mathrm{pH}$ & $\begin{array}{l}\text { Initial glucose } \\
\text { concentration } \\
C_{G}(g / L)\end{array}$ & $\begin{array}{l}\text { Biomass } \\
B_{\mathrm{W}}, \mathrm{CDW}(\mathrm{mg})\end{array}$ & $\begin{array}{l}\text { LA yield } \\
Y_{\text {LA }}(g / g)\end{array}$ & $\begin{array}{l}\text { LA productivity } \\
P_{\mathrm{LA}} \mathrm{g} /(\mathrm{L} \times \mathrm{h})\end{array}$ \\
\hline 1 & 3 & 5 & 110 & 200 & $0.894 \pm 0.006$ & $1.903 \pm 0.013$ \\
\hline 2 & 2 & 5 & 110 & 300 & $0.916 \pm 0.004$ & $2.004 \pm 0.009$ \\
\hline 3 & 3 & 5 & 100 & 300 & $0.907 \pm 0.003$ & $1.838 \pm 0.007$ \\
\hline 4 & 4 & 6 & 110 & 400 & $0.919 \pm 0.002$ & $1.891 \pm 0.007$ \\
\hline 5 & 3 & 6 & 120 & 400 & $0.922 \pm 0.006$ & $2.210 \pm 0.014$ \\
\hline 6 & 4 & 6 & 100 & 300 & $0.924 \pm 0.002$ & $1.828 \pm 0.006$ \\
\hline 7 & 3 & 6 & 110 & 300 & $0.930 \pm 0.001$ & $2.090 \pm 0.003$ \\
\hline 8 & 3 & 6 & 100 & 400 & $0.911 \pm 0.003$ & $1.720 \pm 0.006$ \\
\hline 9 & 4 & 6 & 120 & 300 & $0.908 \pm 0.005$ & $2.117 \pm 0.012$ \\
\hline 10 & 3 & 5 & 110 & 400 & $0.917 \pm 0.006$ & $1.965 \pm 0.014$ \\
\hline 11 & 3 & 6 & 100 & 200 & $0.942 \pm 0.002$ & $1.972 \pm 0.007$ \\
\hline 12 & 2 & 6 & 110 & 400 & $0.934 \pm 0.004$ & $2.071 \pm 0.009$ \\
\hline 13 & 3 & 6 & 110 & 300 & $0.935 \pm 0.001$ & $2.101 \pm 0.004$ \\
\hline 14 & 3 & 6 & 110 & 300 & $0.932 \pm 0.003$ & $2.049 \pm 0.007$ \\
\hline 15 & 3 & 7 & 120 & 300 & $0.871 \pm 0.008$ & $1.975 \pm 0.016$ \\
\hline 16 & 2 & 6 & 100 & 300 & $0.937 \pm 0.002$ & $1.911 \pm 0.006$ \\
\hline 17 & 3 & 7 & 100 & 300 & $0.893 \pm 0.006$ & $1.756 \pm 0.012$ \\
\hline 18 & 3 & 5 & 120 & 300 & $0.897 \pm 0.005$ & $2.059 \pm 0.012$ \\
\hline 19 & 3 & 6 & 110 & 300 & $0.933 \pm 0.002$ & $2.096 \pm 0.005$ \\
\hline 20 & 2 & 7 & 110 & 300 & $0.892 \pm 0.004$ & $1.891 \pm 0.009$ \\
\hline 21 & 3 & 7 & 110 & 400 & $0.866 \pm 0.007$ & $1.782 \pm 0.014$ \\
\hline 22 & 4 & 5 & 110 & 300 & $0.902 \pm 0.003$ & $1.914 \pm 0.006$ \\
\hline 23 & 2 & 6 & 120 & 300 & $0.917 \pm 0.001$ & $2.202 \pm 0.005$ \\
\hline 24 & 4 & 7 & 110 & 300 & $0.883 \pm 0.005$ & $1.815 \pm 0.010$ \\
\hline 25 & 3 & 6 & 110 & 300 & $0.931 \pm 0.003$ & $2.092 \pm 0.007$ \\
\hline 26 & 3 & 6 & 120 & 200 & $0.903 \pm 0.007$ & $1.987 \pm 0.016$ \\
\hline 27 & 3 & 7 & 110 & 200 & $0.894 \pm 0.003$ & $1.902 \pm 0.006$ \\
\hline 28 & 2 & 6 & 110 & 200 & $0.928 \pm 0.002$ & $1.972 \pm 0.004$ \\
\hline 29 & 4 & 6 & 110 & 200 & $0.919 \pm 0.005$ & $2.025 \pm 0.011$ \\
\hline
\end{tabular}

term coefficient, interaction term coefficient, $i$ th factor, and $j$ th factor, respectively (Thakur et al. 2018); whereas, $\varepsilon$ is the random error or uncertainties between predicted values and measured values (Lu et al. 2010).

\section{Results and discussion}

Regression model

For LA yield $\left(Y_{\mathrm{LA}}\right)$, the quadratic model of normalized factors with the value from -1 to 1 is shown as the following format:

$$
\begin{aligned}
Y_{\mathrm{LA}}= & 0.9322-0.0058 \times D_{\mathrm{B}}+0.0112 \times \mathrm{pH}+0.0080 \\
& \times C_{\mathrm{G}}-0.0009 \times B_{\mathrm{W}}+0.0013 \times D_{\mathrm{B}} \times \mathrm{pH} \\
& +0.0010 \times D_{\mathrm{B}} \times C_{\mathrm{G}}-0.0015 \times D_{\mathrm{B}} \times B_{\mathrm{W}} \\
& -0.0030 \times \mathrm{pH} \times C_{\mathrm{G}}-0.0128 \times \mathrm{pH} \times B_{\mathrm{W}} \\
& +0.0125 \times C_{\mathrm{G}} \times B_{\mathrm{W}}-0.0019 \times D_{\mathrm{B}}{ }^{2}-0.0328 \\
& \times \mathrm{pH}^{2}-0.0078 \times C_{\mathrm{G}}{ }^{2}-0.0056 \times B_{\mathrm{W}}{ }^{2} .
\end{aligned}
$$

The actual quadratic model of LA yield has been obtained as follows: 


$$
\begin{aligned}
Y_{\mathrm{LA}}= & -1.05297-0.008400 \times D_{\mathrm{B}}+0.449533 \times \mathrm{pH} \\
& +0.014037 \times C_{\mathrm{G}}-0.000236 \times B_{\mathrm{W}}+0.001250 \\
& \times D_{\mathrm{B}} \times \mathrm{pH}+0.000100 \times D_{\mathrm{B}} \times C_{\mathrm{G}}-0.000015 \\
& \times D_{\mathrm{B}} \times B_{\mathrm{W}}-0.000300 \times \mathrm{pH} \times C_{\mathrm{G}}-0.000128 \\
& \times \mathrm{pH} \times B_{\mathrm{W}}+0.000012 \times C_{\mathrm{G}} \times B_{\mathrm{W}}-0.001892 \\
& \times D_{\mathrm{B}}{ }^{2}-0.032767 \times \mathrm{pH}^{2}-0.000078 \times C_{\mathrm{G}}{ }^{2} \\
& -5.64167 \times 10^{-7} \times B_{\mathrm{W}}{ }^{2} .
\end{aligned}
$$

LA yield model had 15 terms, including four linear terms, four quadratic terms, six terms of two-factorial interaction, and one constant term. The ANOVA of this model is shown in Table 4 . The $F$-value of model was 118.09 with a $p$ value less than 0.0001 , implying that the model was significant (Aslan and Cebeci 2007). The model terms with a $p$-value less than 0.05 could be regarded as highly significant terms in the model ( $\mathrm{Xu}$ and $\mathrm{Xu}$ 2014). Therefore, $D_{\mathrm{B}}, \mathrm{pH}, C_{\mathrm{G}}, \mathrm{pH} \times C_{\mathrm{G}}, \mathrm{pH} \times B_{\mathrm{W}}$, $\mathrm{pH}^{2}, C_{\mathrm{G}}{ }^{2}$, and $B_{\mathrm{W}}{ }^{2}$ were model terms that played a significant role in LA yield by immobilized $L$. pentosus ATCC 8041 cell fermentation. Other model terms with larger $p$-values could be identified to have minor influence on LA yield by immobilized L. pentosus ATCC 8041 cell fermentation. The correlation coefficient $\left(R^{2}\right)$ between experimental results and predicted values of the response variable was used to check the goodness-of-fit formula (Miaou et al. 1996). The $R^{2}$ of LA yield model was 0.9916 , implying that the model was able to describe the trend of experimental result accurately, and only $0.84 \%$ of the sample variation could not be explained by this model (Lu et al. 2010). The adjusted $R^{2}$ and predicted $R^{2}$ were 0.9832 and 0.9572 , respectively, and their difference was less than 0.2 , which indicated that the model value was in a reasonable agreement with a high accuracy (Miaou et al. 1996). The adequate precision of 38.1890 was larger than 4, illustrating that the conditions of immobilized $L$. pentosus ATCC 8041 cell fermentation could be theoretically predicted by this model with a high adequacy. The "Lack of Fit $F$-value" of 2.15 was not significant relative to the pure error, confirming that the significant model

\begin{tabular}{|c|c|c|c|c|c|}
\hline Source & Sum of squares & Degree of freedom & Mean square & $F$-value & $p$-value \\
\hline Model & 0.0111 & 14 & 0.0008 & 118.09 & $<0.0001$ \\
\hline Bead diameter $\left(D_{\mathrm{B}}\right)$ & 0.0004 & 1 & 0.0004 & 58.95 & $<0.0001$ \\
\hline $\mathrm{pH}$ & 0.0015 & 1 & 0.0015 & 222.35 & $<0.0001$ \\
\hline Initial glucose concentration $\left(C_{G}\right)$ & 0.0008 & 1 & 0.0008 & 114.12 & $<0.0001$ \\
\hline Biomass $\left(B_{\mathrm{w}}\right)$ & 0.0000 & 1 & 0.0000 & 1.5 & 0.2411 \\
\hline$D_{\mathrm{B}} \times \mathrm{pH}$ & $6.25 \times 10^{-6}$ & 1 & $6.25 \times 10^{-6}$ & 0.9287 & 0.3515 \\
\hline$D_{B} \times C_{G}$ & $4.00 \times 10^{-6}$ & 1 & $4.00 \times 10^{-6}$ & 0.5944 & 0.4535 \\
\hline$D_{B} \times B_{W}$ & $9.00 \times 10^{-6}$ & 1 & $9.00 \times 10^{-6}$ & 1.34 & 0.2669 \\
\hline $\mathrm{pH} \times \mathrm{C}_{\mathrm{G}}$ & 0.0000 & 1 & 0.0000 & 5.35 & 0.0364 \\
\hline $\mathrm{pH} \times B_{\mathrm{W}}$ & 0.0007 & 1 & 0.0007 & 96.62 & $<0.0001$ \\
\hline$C_{G} \times B_{W}$ & 0.0006 & 1 & 0.0006 & 92.87 & $<0.0001$ \\
\hline$D_{B}^{2}$ & 0.0000 & 1 & 0.0000 & 3.45 & 0.0844 \\
\hline $\mathrm{pH}^{2}$ & 0.007 & 1 & 0.0070 & 1034.84 & $<0.0001$ \\
\hline$C_{G}{ }^{2}$ & 0.0004 & 1 & 0.0004 & 58.14 & $<0.0001$ \\
\hline$B W^{2}$ & 0.0002 & 1 & 0.0002 & 30.68 & $<0.0001$ \\
\hline Residual & 0.0001 & 14 & $6.73 \times 10^{-6}$ & & \\
\hline Lack of fit & 0.0001 & 10 & $7.94 \times 10^{-6}$ & $2.15^{*}$ & 0.2403 \\
\hline Pure error & 0.0000 & 4 & $3.70 \times 10^{-6}$ & & \\
\hline Cor total & 0.0112 & 28 & & & \\
\hline Standard deviation & 0.0026 & & $R^{2}$ & 0.9916 & \\
\hline Mean & 0.9123 & & Adjusted $R^{2}$ & 0.9832 & \\
\hline Coefficient of variation (C.V.\%) & 0.2844 & & Predicted $R^{2}$ & 0.9572 & \\
\hline Press & 0.0005 & & Adequate precision & 38.1890 & \\
\hline
\end{tabular}
was good fitting and reliable (Thakur et al. 2018; Lu et al. 2010; Xu and Xu 2014; Miaou et al. 1996).

The quadratic LA productivity model of normalized factors with the value from -1 to 1 is shown as the following format:

Table 4 ANOVA for LA yield by immobilized L. pentosus ATCC 8041 cells

*Non-significant at $95 \%$ level 


$$
\begin{aligned}
P_{\mathrm{LA}}= & 2.09-0.0384 \times D_{\mathrm{B}}-0.0468 \times \mathrm{pH}+0.1271 \\
& \times C_{\mathrm{G}}-0.0102 \times B_{\mathrm{W}}+0.0035 \times D_{\mathrm{B}} \times \mathrm{pH} \\
& -0.0005 \times D_{\mathrm{B}} \times C_{\mathrm{G}}-0.0583 \times D_{\mathrm{B}} \times B_{\mathrm{W}} \\
& -0.0005 \times \mathrm{pH} \times C_{\mathrm{G}}-0.0455 \times \mathrm{pH} \times B_{\mathrm{W}} \\
& +0.1187 \times C_{\mathrm{G}} \times B_{\mathrm{W}}-0.0339 \times D_{\mathrm{B}}{ }^{2}-0.1386 \\
& \times \mathrm{pH}^{2}-0.0442 \times C_{\mathrm{G}}{ }^{2}-0.0640 \times B_{\mathrm{W}}{ }^{2} .
\end{aligned}
$$

The actual quadratic model of LA productivity $\left(P_{\mathrm{LA}}\right)$ is shown as follows:

$$
\begin{aligned}
P_{\mathrm{LA}}= & -7.26932+0.324383 \times D_{\mathrm{B}}+1.74727 \times \mathrm{pH} \\
& +0.070318 \times C_{\mathrm{G}}-0.004844 \times B_{\mathrm{W}}+0.003500 \\
& \times D_{\mathrm{B}} \times \mathrm{pH}-0.000050 \times D_{\mathrm{B}} \times C_{\mathrm{G}}-0.000582 \\
& \times D_{\mathrm{B}} \times B_{\mathrm{W}}-0.000050 \times \mathrm{pH} \times C_{\mathrm{G}}-0.000455 \\
& \times \mathrm{pH} \times B_{\mathrm{W}}+0.000119 \times C_{\mathrm{G}} \times B_{\mathrm{W}}-0.033925 \\
& \times D_{\mathrm{B}}{ }^{2}-0.138550 \times \mathrm{pH}^{2}-0.000422 \times C_{\mathrm{G}}{ }^{2} \\
& -6.40500 \times 10^{-6} \times B_{\mathrm{W}^{2}} .
\end{aligned}
$$

The LA productivity model contained four linear terms, four quadratic terms, six terms of two-factorial interaction, and one constant term. The ANOVA of this model is shown in Table 5 . In this significant model, $D_{\mathrm{B}}$, $\mathrm{pH}, C_{\mathrm{G}}, D_{\mathrm{B}} \times B_{\mathrm{W}}, \mathrm{pH} \times B_{\mathrm{W}}, C_{\mathrm{G}} \times B_{\mathrm{W}}, D_{\mathrm{B}}{ }^{2}, \mathrm{pH}^{2}, C_{\mathrm{G}}{ }^{2}$, and $B_{\mathrm{W}}{ }^{2}$ could be considered to have main influence on LA productivity as significant terms. The models of LA productivity were also confirmed to be adequate and reliable by ANOVA, which could be used to navigate the design space.

Effect of parameters on immobilized L. pentosus ATCC 8041 cell fermentation

As shown in Figs. 1a-c and 2a-c, LA yield and produc-

\begin{tabular}{|c|c|c|c|c|c|}
\hline Source & Sum of squares & Degree of freedom & Mean square & $F$-value & $p$-value \\
\hline Model & 0.4522 & 14 & 0.0323 & 82.30 & $<0.0001$ \\
\hline Bead diameter $\left(D_{B}\right)$ & 0.0177 & 1 & 0.0177 & 45.12 & $<0.0001$ \\
\hline $\mathrm{pH}$ & 0.0263 & 1 & 0.0263 & 67.06 & $<0.0001$ \\
\hline Initial glucose concentration $\left(C_{G}\right)$ & 0.1938 & 1 & 0.1938 & 493.80 & $<0.0001$ \\
\hline Biomass $\left(B_{w}\right)$ & 0.0012 & 1 & 0.0012 & 3.16 & 0.0972 \\
\hline$D_{B} \times p H$ & 0.0000 & 1 & 0.0000 & 0.1248 & 0.7291 \\
\hline$D_{B} \times C_{G}$ & $1.000 \times 10^{-6}$ & 1 & $1.000 \times 10^{-6}$ & 0.0025 & 0.9605 \\
\hline$D_{B} \times B_{W}$ & 0.0136 & 1 & 0.0136 & 34.58 & $<0.0001$ \\
\hline $\mathrm{pH} \times \mathrm{C}_{\mathrm{G}}$ & $1.000 \times 10^{-6}$ & 1 & $1.000 \times 10^{-6}$ & 0.0025 & 0.9605 \\
\hline $\mathrm{pH} \times B_{\mathrm{W}}$ & 0.0083 & 1 & 0.0083 & 21.10 & 0.0004 \\
\hline$C_{G} \times B_{W}$ & 0.0564 & 1 & 0.0564 & 143.72 & $<0.0001$ \\
\hline$D_{B}{ }^{2}$ & 0.0075 & 1 & 0.0075 & 19.02 & 0.0007 \\
\hline $\mathrm{pH}^{2}$ & 0.1245 & 1 & 0.1245 & 317.26 & $<0.0001$ \\
\hline$C_{G}{ }^{2}$ & 0.0115 & 1 & 0.0115 & 29.40 & $<0.0001$ \\
\hline$B w^{2}$ & 0.0266 & 1 & 0.0266 & 67.80 & $<0.0001$ \\
\hline Residual & 0.0055 & 14 & 0.0004 & & \\
\hline Lack of fit & 0.0037 & 10 & 0.0004 & $0.8594^{*}$ & 0.6171 \\
\hline Pure error & 0.0017 & 4 & 0.0004 & & \\
\hline Cor total & 0.4577 & 28 & & & \\
\hline Standard deviation & 0.0198 & & $R^{2}$ & 0.9880 & \\
\hline Mean & 1.97 & & Adjusted $R^{2}$ & 0.9760 & \\
\hline Coefficient of variation (C.V.\%) & 1.01 & & Predicted $R^{2}$ & 0.9469 & \\
\hline Press & 0.0243 & & Adequate precision & 34.5080 & \\
\hline
\end{tabular}
tivity increase with a decreased bead diameter, indicating the promotion of mass transfer performance and reduction of product inhibition by smaller bead diameter (Wu et al. 2010). As the bead diameter decreased, the surface-to-volume ratio of the beads increased, leading to a decrease in diffusion resistance (Guoqiang et al. 1991). Therefore, the substrate could be more easily diffused into the smaller-sized beads and be utilized by cells, resulting in an increase in product yield and productivity (Park et al. 2002). Idris and Suzana (2006) reported that the maximum LA yield was obtained by immobilized

Table 5 ANOVA for LA productivity by immobilized L. pentosus ATCC 8041 cells

*Non-significant at 95\% level 


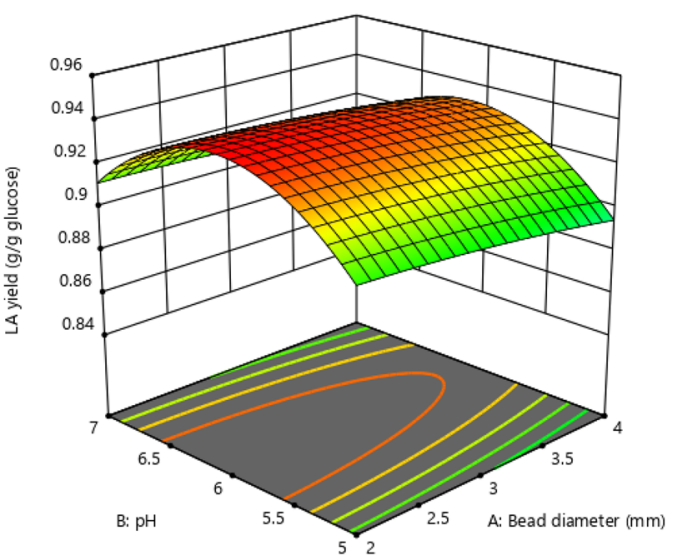

a

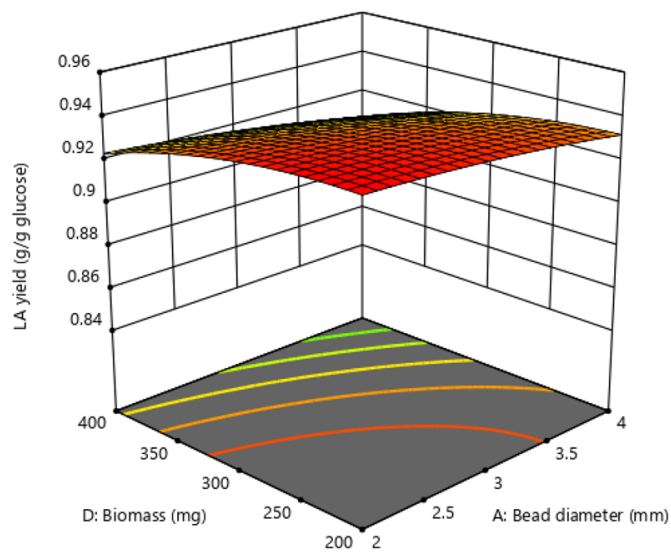

c

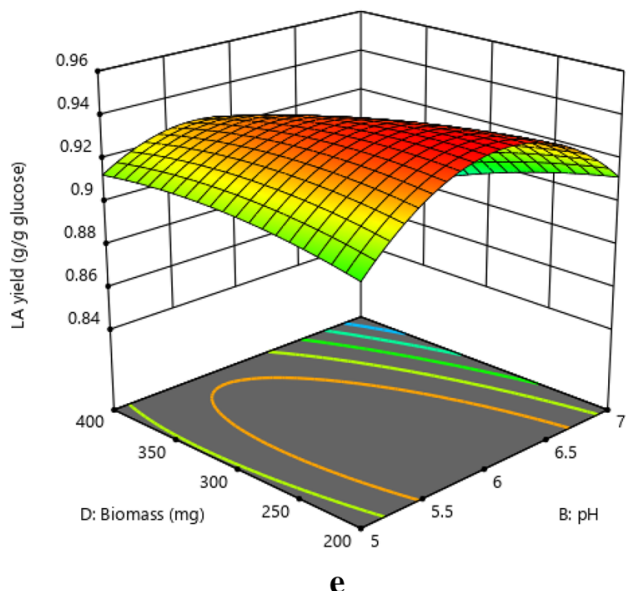

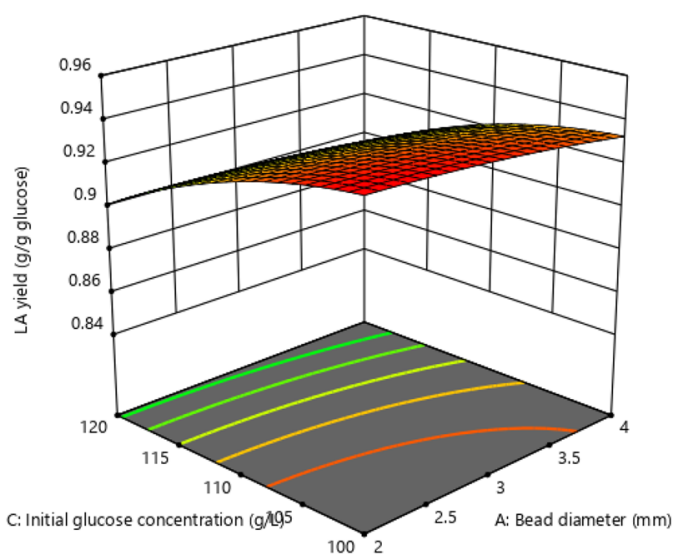

b

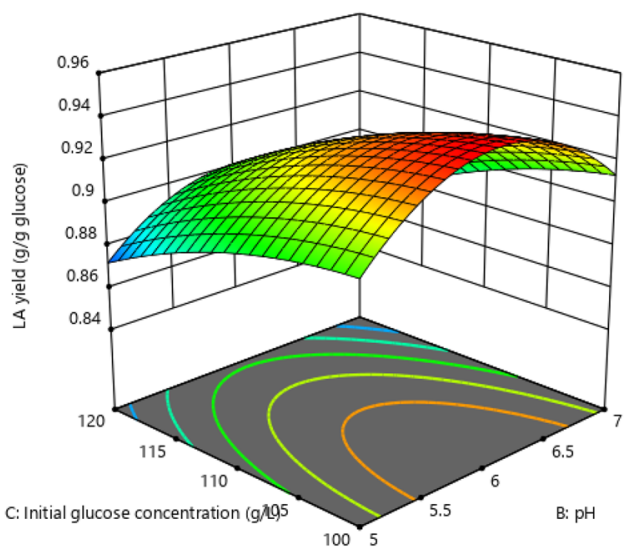

d

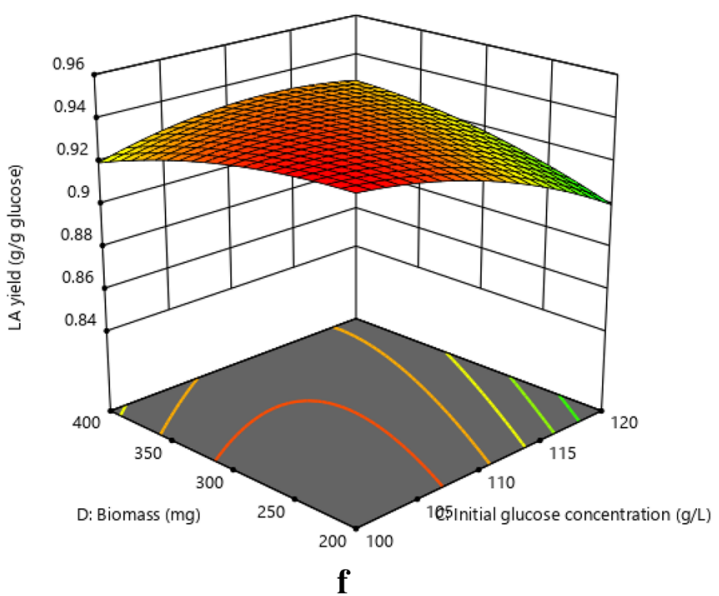

Fig. 1 Response surface of LA yield affected by a bead diameter and pH at 101.9 g/L initial glucose concentration and 204.6 mg biomass (CDW); $\mathbf{b}$ bead diameter and initial glucose concentration at pH 5.99 and $204.6 \mathrm{mg}$ biomass (CDW); c bead diameter and biomass at pH 5.99 and $101.9 \mathrm{~g} / \mathrm{L}$ initial glucose concentration; $\mathbf{d}$ pH and initial glucose concentration at $2.0 \mathrm{~mm}$ bead diameter and $204.6 \mathrm{mg}$ biomass (CDW); e pH and biomass at $2.0 \mathrm{~mm}$ bead diameter and $101.9 \mathrm{~g} / \mathrm{L}$ initial glucose concentration, and $\mathbf{f}$ initial glucose concentration and biomass at $2.0 \mathrm{~mm}$ bead diameter and $\mathrm{pH} 5.99$ 


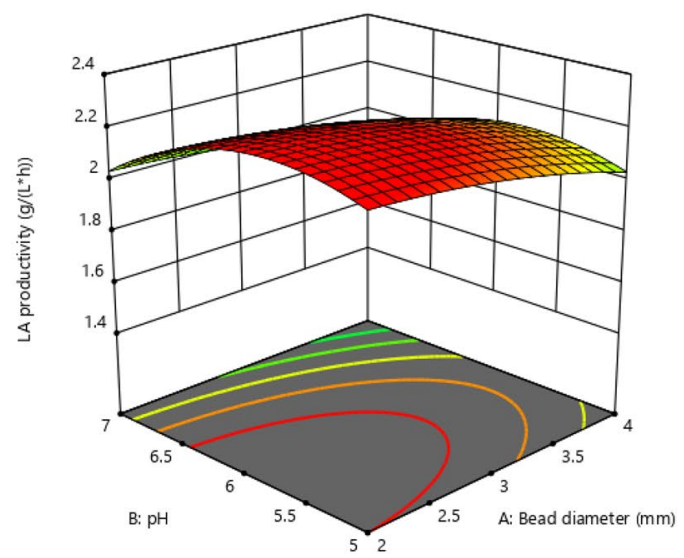

a

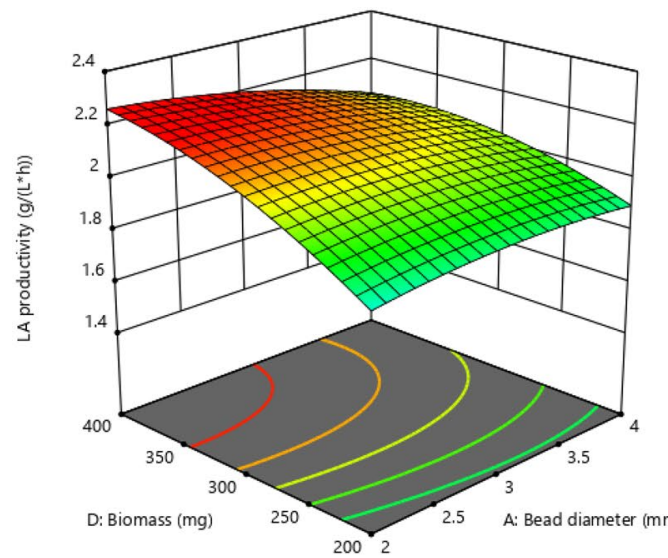

c

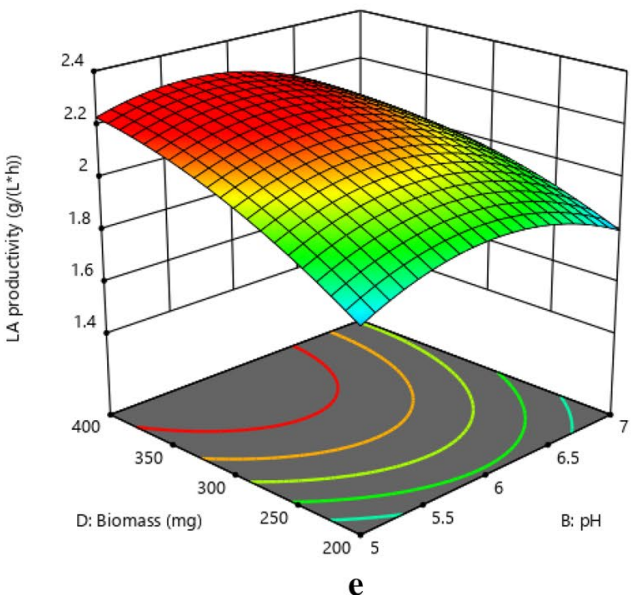

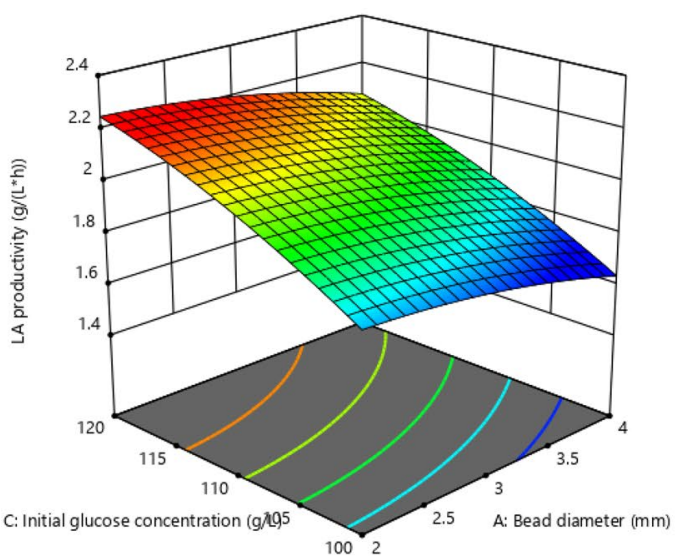

b

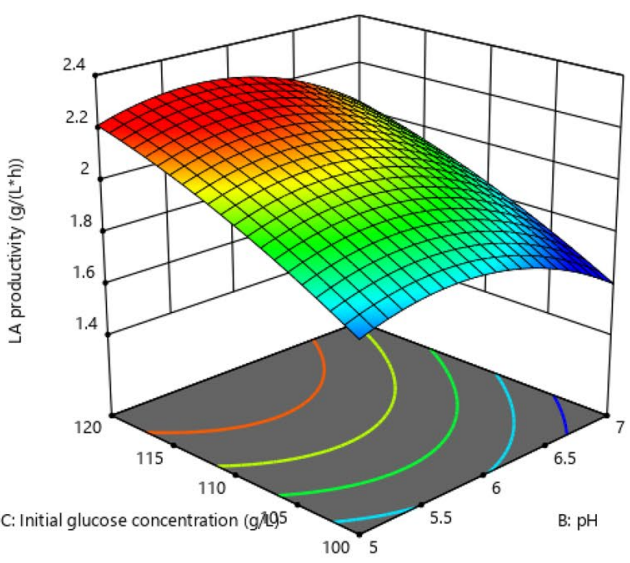

d

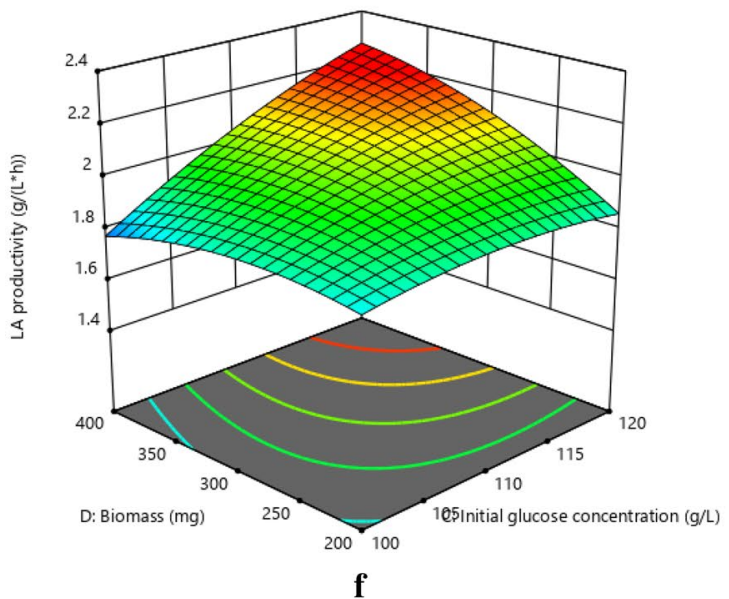

Fig. 2 Response surface of LA productivity affected by a bead diameter and $\mathrm{pH}$ at $119.6 \mathrm{~g} / \mathrm{L}$ initial glucose concentration and $377.4 \mathrm{mg}$ biomass (CDW); $\mathbf{b}$ bead diameter and initial glucose concentration at pH 5.21 and $377.4 \mathrm{mg}$ biomass (CDW); $\mathbf{c}$ bead diameter and biomass at pH 5.21 and $119.6 \mathrm{~g} / \mathrm{L}$ initial glucose concentration; $\mathbf{d}$ pH and initial glucose concentration at $2.0 \mathrm{~mm}$ bead diameter and $377.4 \mathrm{mg}$ biomass (CDW); e pH and biomass at $2.0 \mathrm{~mm}$ bead diameter and $119.6 \mathrm{~g} / \mathrm{L}$ initial glucose concentration, and $\mathbf{f}$ initial glucose concentration and biomass at $2.0 \mathrm{~mm}$ bead diameter and pH 5.21 
Lactobacillus delbrueckii cells with the bead diameter of $1 \mathrm{~mm}$, and the LA yield decreased significantly when the bead diameter was equal to or larger than $5 \mathrm{~mm}$. Park et al. (2002) studied biodegradation of hydrogen sulfide by immobilized Thiobacillus sp. IW and concluded that the biodegradation efficiency increased with a decrease in bead diameter from 4 to $1 \mathrm{~mm}$. It has been reported that substrates with a higher concentration are more easily to diffuse into immobilized cell beads with larger diameter (Idris and Suzana 2006; Dwevedi and Kayastha 2009; Won et al. 2005). Other reports point out that larger numbers of cells were contained in the particles with a larger diameter, which cause a higher rate of substrate consumption (Wu et al. 2010; Won et al. 2005; Mundra et al. 2007; Gummadi et al. 2009). Therefore, the LA productivity increases with a properly increased bead diameter from 2 to $3 \mathrm{~mm}$ due to an increased initial glucose concentration and amount of biomass, while it decreases with the further increased bead diameter due to the substrate consumption for cell growth as shown in Fig. 2b, c.

As shown in Fig. 1a, d, e, the highest LA yield has been observed at around $\mathrm{pH} 6.0$ by immobilized L. pentosus ATCC 8041 cell fermentation, while the highest LA productivity has been obtained at around $\mathrm{pH} 5.5$ as shown in Fig. 2a, d, e. The same result was also obtained by Bahry et al. (2019) and Krischke et al. (1991) in the fermentation process of different immobilized cells. A higher external $\mathrm{pH}$ inhibited the activity of the ATPase combined with a change in $\mathrm{pH}$ of cytoplasm, resulting in a decrease in fermentation efficiency (Valli et al. 2005; Kourkoutas et al. 2004; Carmelo et al. 1997). Liu and Shen (2008) studied the effect of $\mathrm{pH}$ on ethanol production by immobilized $S$. cerevisiae. They indicated that the $\mathrm{H}^{+}$in the fermentation broth diffused freely to the inside of the immobilized cell particles through the large pores of the calcium alginate matrix and caused a change in charge quantities of the plasma membrane, which led to a change in the permeability of the plasma membrane to nutrients and inorganic salt ions, affecting the fermentation efficiency. Another research showed that extreme acidic $\mathrm{pH}$ caused changes in intracellular ionic environment and damages to protein structure, which was detrimental to cell growth and metabolism, leading to a decrease in product yield and productivity (Bhushan et al. 2015). It has also been reported that the inhibitory effect of LA with the undissociated form on LA production is more significant than that of the dissociated lactate form if the $\mathrm{pH}$ is closer to the pKa of LA (about 3.9) (Pal et al. 2009). When pH is lower than 5, LA production will be inhibited because of the increased amount of LA with the undissociated form, while LA production will also be inhibited due to the inhibited activity of related enzymes when $\mathrm{pH}$ is higher than 7 (Bahry et al. 2019). Therefore, the $\mathrm{pH}$ value from 5.5 to 6.0 is an ideal condition for LA production by fermentation process. When the concentrations of initial glucose and biomass were low, LA yield of immobilized L. pentosus ATCC 8041 cells at $\mathrm{pH} 7.0$ was higher than that at $\mathrm{pH} 5.0$, and its change from $\mathrm{pH} 5-6$ was faster than that from $\mathrm{pH}$ 6.0-7.0. However, LA productivity of immobilized L. pentosus ATCC 8041 cells at pH 7.0 was lower than that at $\mathrm{pH} 5.0$, and its change from $\mathrm{pH} 5.0$ 6.0 was slower than that from $\mathrm{pH}$ 6.0-7.0. It indicated that the cell growth of L. pentosus at pH 5 was more significant than that at $\mathrm{pH} 7$. The enzyme activity for cell growth of L. pentosus was higher at $\mathrm{pH} 5.0$ due to its acid-resistivity, and more glucose was consumed for cell growth rather than LA production at $\mathrm{pH}$ 5.0. When $\mathrm{pH}$ increased to be 7.0, the enzyme activity for cell growth was inhibited, and more glucose was utilized to produce LA (Buyondo and Liu 2013). When the concentrations of initial glucose and biomass were high, both LA yield and productivity were lower at $\mathrm{pH} 7.0$ than that at $\mathrm{pH}$ 5.0.

As shown in Figs. 1b, d, f and 2b, d, f, an increased initial glucose concentration leads to a decreased LA yield but an increased LA productivity. It indicates that the initial glucose concentration increasing in a certain range would promote cell growth and subsequently promoted the LA productivity, while the LA yield was inhibited due to the limited substrate and enzyme activity (Bahry et al. 2019; Thakur et al. 2018; Liu et al. 2018). Qin et al. (2009) reported that the initial glucose concentration has a significant effect on LA production in batch fermentation. They found that an initial glucose concentration of $9.7 \%$ to $13.3 \%$ had non-significant limitation to the LA production, but an initial glucose concentration of $18.6 \%$ or higher would lead to a significant restriction on LA production. The similar result was also found by Wendhausen et al. (2001) that the initial glucose concentration strongly affected ethanol production of immobilized $S$. cerevisiae in batch fermentation of sugar cane syrup. A study reported that a higher glucose concentration leads to a longer retention time required to obtain a higher product yield due to a lower feed dilution (Liu et al. 2009). Feed dilution causes osmotic effects on the mass transfer performance and cell activity, leading to changes in product yield and productivity (Lee et al. 2011). Wada et al. (1980) studied effects of different glucose concentrations on the growth and production activity of immobilized cells and concluded that the largest number of cells in the gel beads was obtained by using a medium with the glucose concentration of $10 \%$. They found that increased glucose concentration out of proper range caused a decrease in cell growth rate and number of viable cells in the gel, resulting in a reduction of product yield and productivity. Other reports explained 
that the reduced water activity and plasmolysis led to decreased cell activity or cell dormancy when the substrate concentration exceeded the critical value, resulting in a decrease in fermentation efficiency (Roukas et al. 1991; Tapia et al. 2008). However, the result reported by Mariam et al. (2009) was different from the result shown in Fig. 1, which concluded that the sugar concentration of $15 \%$ led to the maximum product yield in both free cell fermentation and immobilized cell fermentation. As shown in Figs. If and 2f, when the amount of cell is lower, the product yield and productivity increases with the increase of the substrate concentration, and when the substrate concentration exceeds the critical value, the product yield and productivity show a decreasing trend with the increase of the substrate concentration (Liu et al. 2008).

As shown in Figs. 1c, e, f and 2c, e, f, regardless of other parameters, the increased amount of cell biomass results in a decrease in LA yield but an increase in LA productivity. The same result was obtained by Dong et al. (2017). They reported that more substrate was consumed for the cell growth and the maintenance for physiological activities of cells when the cell concentration was higher, resulting in a significant decrease in product yield due to substrate deficiency. As shown in Fig. 1f, with the sufficient substrate concentration, product yield increases as the amount of entrapped cells rose. When the substrate concentration is low, nutrients are not enough to support cell growth and metabolism for a larger amount of cells, resulting in a decrease in product yield due to the limited metabolism rate (Thakur et al. 2018). As shown in Fig. 2f, when the glucose concentration is low, the LA productivity decreases with the increase in biomass from 200 to $300 \mathrm{mg}$ caused by the glucose consumption for cell growth. However, LA productivity increases with the further increase in amount of biomass. When the glucose concentration is high, the increased number of cells in a certain period of time promotes LA production with richer substrates, which lead to an increase in LA productivity. In addition, an extremely low cell density would lead to the cell growth to become the main activity of cells in the initial stage of fermentation, which subsequently causes a decrease in product yield and productivity (Wendhausen et al. 2001; Liu et al. 2009; Wada et al. 1980; Roukas et al. 1991; Tapia et al. 2008; Dong et al. 2017). Furthermore, it was observed that cell growth in immobilized cell particles led to the formation of distinct and large colonies when the concentration of the entrapped cells was low, and the size of colonies increased as the concentration of the captured cells reduced (Walsh et al. 1996). However, this result was not in agreement with that of Bhatnagar et al. (2016). They studied the biodegradation of carbazole by immobilized
Pseudomonas sp. GBS.5 cells and concluded that the rate of biodegradation did not enhance with an increase in entrapped cell concentration when the substrate concentration is appropriate.

\section{Optimization of LA production and validation test}

Fermentation conditions for the highest LA yield and the highest LA productivity were numerically optimized, respectively. It was estimated based on the mathematical model that the highest LA yield was $0.942 \mathrm{~g} / \mathrm{g}$ glucose with a productivity of $1.947 \mathrm{~g} /(\mathrm{L} \times \mathrm{h})$ at $2.0 \mathrm{~mm}$ bead diameter, $5.99 \mathrm{pH}, 101.9 \mathrm{~g} / \mathrm{L}$ initial glucose concentration, and $204.611 \mathrm{mg}$ biomass (CDW). However, the highest LA productivity was estimated as $2.242 \mathrm{~g} /(\mathrm{L} \times \mathrm{h})$ with a yield of $0.926 \mathrm{~g} / \mathrm{g}$ glucose at $2.0 \mathrm{~mm}$ bead diameter, $5.21 \mathrm{pH}, 119.6 \mathrm{~g} / \mathrm{L}$ initial glucose concentration, and $377.4 \mathrm{mg}$ biomass (CDW). In order to validate the effectiveness of estimated optimum conditions, a batch fermentation of immobilized L. pentosus ATCC 8041 cells under the estimated optimum conditions were carried out at $35{ }^{\circ} \mathrm{C}$ and $150 \mathrm{rpm}$ in a complete fermentation period of $48 \mathrm{~h}$. The experimental result of highest LA yield test was obtained as $0.941 \pm 0.004 \mathrm{~g} / \mathrm{g}$ glucose with a productivity of $1.950 \pm 0.011 \mathrm{~g} /(\mathrm{L} \times \mathrm{h})$, while the data of highest LA productivity test was obtained as $2.245 \pm 0.007 \mathrm{~g} /$ $(\mathrm{L} \times \mathrm{h})$ with a yield of $0.928 \pm 0.005 \mathrm{~g} / \mathrm{g}$ glucose. Therefore, the close correspondence could be observed between the experimental data and the predicted result by mathematical model.

Due to the different optimum conditions for LA yield and productivity, the conditions should be optimized to obtain a higher LA yield and productivity simultaneously for practical application. The conditions optimized by this method can effectively improve the product conversion rate and fermentation efficiency during the fermentation process, which leads to a reduction of costs and fermentation period (Thakur et al. 2018). Based on the mathematical model, the highest LA yield and productivity were obtained as $0.936 \mathrm{~g} / \mathrm{g}$ glucose and $2.210 \mathrm{~g} /$ $(\mathrm{L} \times \mathrm{h})$, respectively. The estimated scheme of optimum condition was obtained as the bead meter of $2.0 \mathrm{~mm}$, the $\mathrm{pH}$ value of 5.60 , the initial glucose concentration of $115.3 \mathrm{~g} / \mathrm{L}$, and the biomass (CDW) of $398.2 \mathrm{mg}$. The result of the validation experiment was obtained as the LA yield of $0.938 \pm 0.003 \mathrm{~g} / \mathrm{g}$ glucose and a productivity of $2.213 \pm 0.008 \mathrm{~g} /(\mathrm{L} \times \mathrm{h})$, which also confirmed a high reliability of this model. The density of viable cells was obtained as $8.13 \times 10^{9} \mathrm{CFU} / \mathrm{g}(9.91 \mathrm{log} \mathrm{CFU} / \mathrm{g})$ beads, implying that the immobilized L. pentosus ATCC 8041 cells had high viability in batch fermentation under optimum conditions. The batch fermentation of free L. pentosus ATCC 8041 cells was also conducted under the 


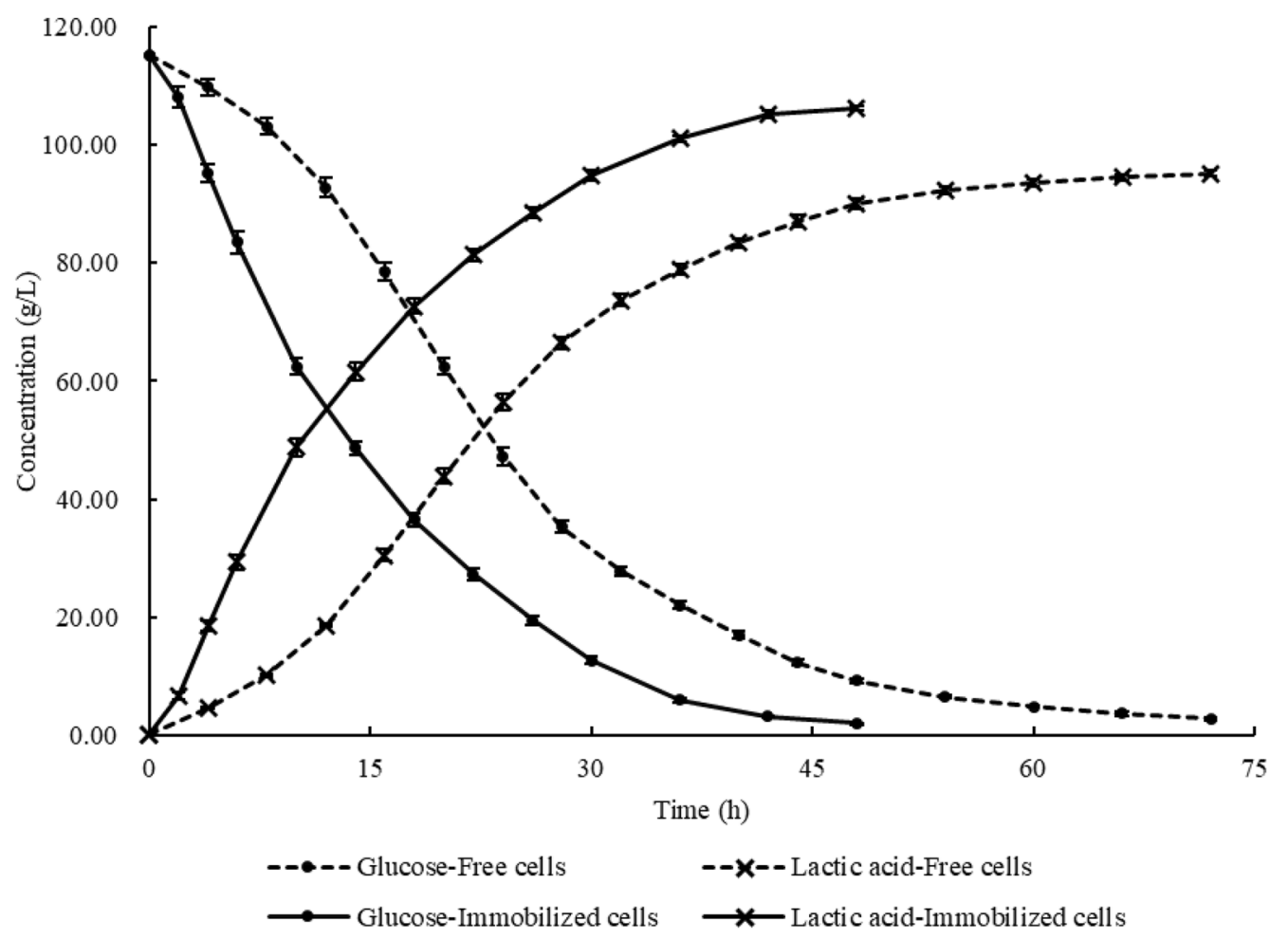

Fig. 3 Time profiles of $L A$ and glucose concentrations during the fermentation process of immobilized $L$. pentosus ATCC 8041 cells and free $L$. pentosus ATCC 8041 cells

Table 6 The results of repeated batch fermentation of immobilized L. pentosus ATCC 8041 cells under optimum conditions

\begin{tabular}{|c|c|c|c|c|}
\hline Batch number & $\begin{array}{l}\text { Residual glucose concentration } \\
C_{G}(g / L)\end{array}$ & $\begin{array}{l}\text { LA concentration } \\
C_{\mathrm{LA}}(\mathrm{g} / \mathrm{L})\end{array}$ & $\begin{array}{l}\text { LA yield } \\
Y_{\text {LA }}(g / g)\end{array}$ & $\begin{array}{l}\text { LA productivity } \\
P_{\text {LA }} g /(L \times h)\end{array}$ \\
\hline 1 & $2.06 \pm 0.31$ & $106.22 \pm 0.34$ & $0.938 \pm 0.003$ & $2.213 \pm 0.007$ \\
\hline 2 & $1.12 \pm 0.27$ & $106.75 \pm 0.48$ & $0.935 \pm 0.004$ & $2.224 \pm 0.010$ \\
\hline 3 & $1.75 \pm 0.42$ & $106.85 \pm 0.67$ & $0.941 \pm 0.006$ & $2.226 \pm 0.014$ \\
\hline 4 & $1.63 \pm 0.34$ & $106.51 \pm 0.39$ & $0.937 \pm 0.003$ & $2.219 \pm 0.008$ \\
\hline 5 & $1.54 \pm 0.23$ & $106.70 \pm 0.58$ & $0.938 \pm 0.005$ & $2.223 \pm 0.012$ \\
\hline 6 & $2.04 \pm 0.31$ & $106.46 \pm 0.63$ & $0.940 \pm 0.006$ & $2.218 \pm 0.012$ \\
\hline 7 & $1.88 \pm 0.34$ & $106.27 \pm 0.37$ & $0.937 \pm 0.003$ & $2.214 \pm 0.008$ \\
\hline 8 & $1.34 \pm 0.41$ & $106.42 \pm 0.54$ & $0.934 \pm 0.005$ & $2.217 \pm 0.011$ \\
\hline
\end{tabular}

same fermentation conditions. It was observed to take approximately $72 \mathrm{~h}$ in free L. pentosus ATCC 8041 cell fermentation for glucose to be consumed almost completely with a LA yield of $0.826 \pm 0.004 \mathrm{~g} / \mathrm{g}$ glucose and a productivity of $1.323 \pm 0.006 \mathrm{~g} /(\mathrm{L} \times \mathrm{h})$. The changes of LA and glucose concentrations during the fermentation process of both immobilized L. pentosus ATCC 8041 cells and free L. pentosus ATCC 8041 cells are shown in Fig. 3. Therefore, the LA yield and LA productivity of immobilized L. pentosus ATCC 8041 cells were $13.6 \%$ and $67.3 \%$ higher than that of free L. pentosus ATCC 8041 cells, respectively. The high LA yield and productivity obtained in the validation experiment indicated the high fermentation efficiency and excellent stability of the immobilized L. pentosus ATCC 8041 cells during the fermentation process under the optimum conditions. Repeated batch fermentation was also conducted to test the reusability of immobilized L. pentosus ATCC 8041 cells. As shown in Table 6, immobilized L. pentosus ATCC 8041 cells can maintain stable fermentation performance in 8 batches of 
fermentation to reach a high LA yield and productivity, implying that immobilized L. pentosus ATCC 8041 cells have excellent reusability.

The maximum LA yield of $0.96 \mathrm{~g} / \mathrm{g}$ substrate with a productivity of $1.69 \mathrm{~g} /(\mathrm{L} \times \mathrm{h})$ was obtained by DjukićVuković et al. in the study of non-mineral LA fermentation by immobilized Lactobacillus rhamnosus ATCC 7469 cells, and they also obtained the maximum LA yield of $0.96 \mathrm{~g} / \mathrm{g}$ substrate with a productivity of $1.41 \mathrm{~g} /(\mathrm{L} \times \mathrm{h})$ by immobilized L. rhamnosus ATCC 7469 cell fermentation without nitrogen source (Djukić-Vuković et al. 2013, 2016). Radosavljević et al. (2019) studied immobilization of $L$. rhamnosus in PVA-SA hydrogel for LA production and obtained the maximum LA productivity of $0.8 \mathrm{~g} /$ $(\mathrm{L} \times \mathrm{h})$ in batch fermentation and an overall productivity of $0.78 \mathrm{~g} /(\mathrm{L} \times \mathrm{h})$ in seven batches of repeated batch fermentation. Hajar et al. obtained the maximum LA productivity of $1.22 \mathrm{~g} /(\mathrm{L} \times \mathrm{h})$ in immobilized L. rhamnosus cell fermentation of carob pod waste (Bahry et al. 2019). The maximum LA yield of $0.93 \mathrm{~g} / \mathrm{g}$ glucose with a productivity of $2.7 \mathrm{~g} /(\mathrm{L} \times \mathrm{h})$ in immobilized Lactobacillus casei cell fermentation with a dry cell concentration of $7.5 \mathrm{~g} / \mathrm{L}$ was obtained by Maslova et al. (2016).

\section{Conclusion}

The immobilized $L$. pentosus cells perform with a high fermentation efficiency and excellent stability in homofermentation for LA production. The parameters have been optimized to be $2.0 \mathrm{~mm}$ bead diameter, $5.60 \mathrm{pH}$, $115.3 \mathrm{~g} / \mathrm{L}$ initial glucose concentration, and $398.2 \mathrm{mg}$ biomass $(\mathrm{CDW})$ based on response surface methodology with Box-Behnken design for maximizing the LA yield. The highest LA yield and productivity have been obtained as $0.938 \pm 0.003 \mathrm{~g} / \mathrm{g}$ glucose and $2.213 \pm 0.008 \mathrm{~g} /(\mathrm{L} \times \mathrm{h})$, respectively. The stable and high LA yield and productivity can be obtained by repeated batch fermentation by L. pentosus cells under optimum conditions.

The LA yield and glucose consumption rate of immobilized $L$. pentosus cells can be optimized with a quadratic model with a high accuracy, which can be used to navigate a design space.

\section{Abbreviations \\ LA: Lactic acid; PLA: Polylactic acid; LAB: Lactic acid bacteria; SA: Sodium alginate; PVA: Polyvinyl alcohol; EMP: Embden-Meyerhof-Parnas; PK: Phospho- ketolase; DOE: Design of experiment; ATCC: American Type Culture Collection; MRS: de Man, Rogosa and Sharpe; NMR: Nuclear magnetic resonance; ANOVA: Analysis of variance.}

\section{Acknowledgements}

The authors thank SUNY College of Environmental Science and Forestry for the help and support in this study.

\section{Authors' contributions}

JW and SL are the primary contributors of this work. JH provided important technical support for experiments and manuscript preparation. HL, SJ, JZ,
$\mathrm{YN}$, and MF supported in the manuscript preparation. All authors read and approved the final manuscript.

Funding

Not applicable.

Availability of data and materials

All data obtained or analyzed during this study are included in this article and available from the corresponding author.

Ethics approval and consent to participate

Not applicable.

\section{Consent for publication}

The publication of the paper has been agreed by the authors.

\section{Competing interests}

The authors declare that they have no potential conflicts of interest.

\section{Author details}

${ }^{1}$ Department of Paper and Bioprocess Engineering, SUNY College of Environmental Science and Forestry, Syracuse, NY 13210, USA. ${ }^{2}$ The Center for Biotechnology \& Interdisciplinary Studies (CBIS) at Rensselaer Polytechnic Institute, Troy, NY 12180, USA.

Received: 14 January 2020 Accepted: 16 March 2020

Published online: 20 March 2020

\section{References}

Abdel-Rahman MA, Tashiro Y, Sonomoto K (2011) Lactic acid production from lignocellulose-derived sugars using lactic acid bacteria: overview and limits. J Biotechnol 156(4):286-301

Al-Gheethi A, Noman E, Mohamed RMSR, Ismail N, Abdullah AHB, Kassim AHM (2019) Optimizing of pharmaceutical active compounds biodegradability in secondary effluents by $\beta$-lactamase from Bacillus subtilis using central composite design. J Hazard Mater 365:883-894

Aslan N, Cebeci Y (2007) Application of Box-Behnken design and response surface methodology for modeling of some Turkish coals. Fuel 86(1-2):90-97

Bahry H, Abdalla R, Pons A, Taha S, Vial C (2019) Optimization of lactic acid production using immobilized Lactobacillus rhamnosus and carob pod waste from the Lebanese food industry. J Biotechnol 306:81-88

Bhatnagar Y, Singh GB, Mathur A, Srivastava S, Gupta S, Gupta N (2016) Biodegradation of carbazole by Pseudomonas sp. GBS. 5 immobilized in polyviny alcohol beads. J Biochem Technol 6(3):1003-1007

Bhushan B, Pal A, Jain V (2015) Improved enzyme catalytic characteristics upon glutaraldehyde cross-linking of alginate entrapped xylanase isolated from Aspergillus flavus MTCC 9390. Enzyme Res. https://doi. org/10.1155/2015/210784

Buyondo JP, Liu S (2013) Unstructured kinetic modeling of batch production of lactic acid from hemicellulosic sugars. J Bioprocess Eng Biorefin 2(1):40-45

Carmelo V, Santos H, SaCorreia I (1997) Effect of extracellular acidification on the activity of plasma membrane ATPase and on the cytosolic and vacuolar pH of Saccharomyces cerevisiae. Biochim Biophys Acta 1325(1):63-70

Chollom MN, Rathilal S, Swalaha FM, Bakare BF, Tetteh EK, Chollom MN, Rathilal S, Swalaha FM, Bakare BF, Tetteh EK (2019) Comparison of response surface methods for the optimization of an upflow anaerobic sludge blanket for the treatment of slaughterhouse wastewater. Environ Eng Res 25(1):114-122

Dishisha T, Alvarez MT, Hatti-Kaul R (2012) Batch and continuous propionic acid production from glycerol using free and immobilized cells of Propionibacterium acidipropionici. Bioresour Technol 118:553-5622

Djukić-Vuković AP, Mojović LV, Jokić BM, Nikolić SB, Pejin JD (2013) Lactic acid production on liquid distillery stillage by Lactobacillus rhamnosus immobilized onto zeolite. Bioresour Technol 135:454-458

Djukić-Vuković AP, Jokić BM, Kocić-Tanackov SD, Pejin JD, Mojović LV (2016) Mg-modified zeolite as a carrier for Lactobacillus rhamnosus in L (+) 
lactic acid production on distillery wastewater. J Taiwan Inst Chem Eng 59:262-266

Dong Y, Zhang Y, Tu B (2017) Immobilization of ammonia-oxidizing bacteria by polyvinyl alcohol and sodium alginate. Braz J Microbiol 48(3):515-521

Dwevedi A, Kayastha AM (2009) Optimal immobilization of $\beta$-galactosidase from Pea (PsBGAL) onto sephadex and chitosan beads using response surface methodology and its applications. Bioresour Technol 100(10):2667-2675

Ghorbani F, Younesi H, Sari AE, Najafpour G (2011) Cane molasses fermentation for continuous ethanol production in an immobilized cells reactor by Saccharomyces cerevisiae. Renew Energy 36(2):503-509

Goranov B, Blazheva D, Kostov G, Denkova Z, Germanova Y (2013) Lactic acid fermentation with encapsulated Lactobacillus casei ssp. rhamnosus ATCC 11979 (NBIMCC 1013) in alginate/chitosan matrices. Bulg J Agric Sci 19(2):101-104

Gummadi SN, Ganesh K, Santhosh D (2009) Enhanced degradation of caffeine by immobilized cells of Pseudomonas sp. in agar-agar matrix using statistical approach. Biochem Eng J 44(2-3):136-141

Guoqiang D, Kaul R, Mattiasson B (1991) Evaluation of alginate-immobilized Lactobacillus casei for lactate production. Appl Microbiol Biotechnol 36(3):309-314

Holzgrabe U (2010) Quantitative NMR spectroscopy in pharmaceutical applications. Prog Nucl Magn Reson Spectrosc 57(2):229-240

Huang J, Zhang G, Zheng L, Lin Z, Wu Q, Pan Y (2019) Plackett-Burman design and response surface optimization of conditions for culturing Saccharomyces cerevisiae in Agaricus bisporus industrial wastewater. Acta Sci Pol Technol Aliment. https://doi.org/10.17306/J.AFS.2019.0620

Idris A, Suzana W (2006) Effect of sodium alginate concentration, bead diameter, initial $\mathrm{pH}$ and temperature on lactic acid production from pineapple waste using immobilized Lactobacillus delbrueckii. Process Biochem 41(5):1117-1123

Kourkoutas Y, Bekatorou A, Banat IM, Marchant R, Koutinas A (2004) Immobilization technologies and support materials suitable in alcohol beverages production: a review. Food Microbiol 21(4):377-397

Krischke W, Schröder M, Trösch W (1991) Continuous production of L-lactic acid from whey permeate by immobilized Lactobacillus casei subsp. casei. Appl Microbiol Biotechnol 34(5):573-578

Kumar MN, Gialleli Al, Masson JB, Kandylis P, Bekatorou A, Koutinas AA, Kanellaki M (2014) Lactic acid fermentation by cells immobilised on various porous cellulosic materials and their alginate/poly-lactic acid composites. Bioresour Technol 165:332-335

Laopaiboon P, Thani A, Leelavatcharamas V, Laopaiboon L (2010) Acid hydrolysis of sugarcane bagasse for lactic acid production. Bioresour Technol 101(3):1036-1043

Lee KY, Mooney DJ (2012) Alginate: properties and biomedical applications. Prog Polym Sci 37(1):106-126

Lee KH, Choi IS, Kim YG, Yang DJ, Bae HJ (2011) Enhanced production of bioethanol and ultrastructural characteristics of reused Saccharomyces cerevisiae immobilized calcium alginate beads. Bioresour Technol 102(17):8191-8198

Liu R, Shen F (2008) Impacts of main factors on bioethanol fermentation from stalk juice of sweet sorghum by immobilized Saccharomyces cerevisiae (CICC 1308). Bioresour Technol 99(4):847-854

Liu YP, Zheng P, Sun ZH, Ni Y, Dong JJ, Zhu LL (2008) Economical succinic acid production from cane molasses by Actinobacillus succinogenes. Bioresour Technol 99(6):1736-1742

Liu CZ, Wang F, Ou-Yang F (2009) Ethanol fermentation in a magnetically fluidized bed reactor with immobilized Saccharomyces cerevisiae in magnetic particles. Bioresour Technol 100(2):878-882

Liu J, Pan D, Wu X, Chen H, Cao H, Li QX, Hua R (2018) Enhanced degradation of prometryn and other s-triazine herbicides in pure cultures and wastewater by polyvinyl alcohol-sodium alginate immobilized Leucobacter sp. JW-1. Sci Total Environ 615:78-86

Lu Z, He F, Shi Y, Lu M, Yu L (2010) Fermentative production of L (+)-lactic acid using hydrolyzed acorn starch, persimmon juice and wheat bran hydrolysate as nutrients. Bioresour Technol 101(10):3642-3648

Mariam I, Manzoor K, Ali S, UI-Haq I (2009) Enhanced production of ethanol from free and immobilized Saccharomyces cerevisiae under stationary culture. Pak J Bot 41(2):821-833
Martinez FAC, Balciunas EM, Salgado JM, González JMD, Converti A, de Souza Oliveira RP (2013) Lactic acid properties, applications and production: a review. Trends Food Sci Technol 30(1):70-83

Maslova O, Sen'ko O, Stepanov N, Efremenko E (2016) Lactic acid production using free cells of bacteria and filamentous fungi and cells immobilized in polyvinyl alcohol cryogel: a comparative analysis of the characteristics of biocatalysts and processes. Catal Ind 8(3):280-285

Miaou SP, Lu A, Lum HS (1996) Pitfalls of using R2 to evaluate goodness of fit of accident prediction models. Transp Res Rec 1542(1):6-13

Mittal A, Scott GM, Amidon TE, Kiemle DJ, Stipanovic AJ (2009) Quantitative analysis of sugars in wood hydrolyzates with 1 H NMR during the autohydrolysis of hardwoods. Bioresour Technol 100(24):6398-6406

Mundra P, Desai K, Lele S (2007) Application of response surface methodology to cell immobilization for the production of palatinose. Bioresour Technol 98(15):2892-2896

Okano K, Zhang Q, Yoshida S, Tanaka T, Ogino C, Fukuda H, Kondo A (2010) D-lactic acid production from cellooligosaccharides and $\beta$-glucan using L-LDH gene-deficient and endoglucanase-secreting Lactobacillus plantarum. Appl Microbiol Biotechnol 85(3):643-650

Pal P, Sikder J, Roy S, Giorno L (2009) Process intensification in lactic acid production: a review of membrane based processes. Chem Eng Process 48(11-12):1549-1559

Park DH, Cha JM, Ryu HW, Lee GW, Yu EY, Rhee JI, Park JJ, Kim SW, Lee IW, Joe YI (2002) Hydrogen sulfide removal utilizing immobilized Thiobacillus sp. IW with Ca-alginate bead. Biochem Eng J 11(2-3):167-173

Poncelet D, Neufeld R, Goosen M, Burgarski B, Babak V (1999) Formation of microgel beads by electric dispersion of polymer solutions. AlChE J 45(9):2018-2023

Qin J, Zhao B, Wang X, Wang L, Yu B, Ma Y, Ma C, Tang H, Sun J, Xu P (2009) Non-sterilized fermentative production of polymer-grade L-lactic acid by a newly isolated thermophilic strain Bacillus sp. 2-6. PLoS ONE 4(2):e4359

Radosavljević M, Lević S, Belović M, Pejin J, Djukić-Vuković A, Mojović L, Nedović V (2019) Immobilization of Lactobacillus rhamnosus in polyvinyl alcohol/calcium alginate matrix for production of lactic acid. Bioprocess Biosyst Eng. https://doi.org/10.1007/s00449-019-02228-0

Roukas T, Lazarides H, Kotzekidou P (1991) Ethanol production from deproteinized whey by Saccharomyces cerevisiae cells entrapped in different immobilization matrices. Milchwissenschaft 46(7):438-441

Sahin S (2019) Optimization of the immobilization conditions of horseradish peroxidase on $\mathrm{TiO}_{2}-\mathrm{COOH}$ nanoparticles by Box-Behnken design. J Nat Appl Sci. https://doi.org/10.19113/sdufenbed.557021

Tang Y, Pang L, Wang D (2017) Preparation and characterization of borate bioactive glass cross-linked PVA hydrogel. J Non-Cryst Solids 476:25-29

Tapia MS, Alzamora SM, Chirife J (2008) 10 effects of water activity ( $a_{w}$ ) on microbial stability: as a hurdle in food preservation. Water activity foods. Wiley, New York

Thakur A, Panesar PS, Saini MS (2018) Parametric optimization of lactic acid production by immobilized Lactobacillus casei using Box-Behnken design. Periodica Polytech Chem Eng 62(3):274-285

Valli M, Sauer M, Branduardi P, Borth N, Porro D, Mattanovich D (2005) Intracellular pH distribution in Saccharomyces cerevisiae cell populations, analyzed by flow cytometry. Appl Environ Microbiol 71(3):1515-1521

Vijayakumar J, Aravindan R, Viruthagiri T (2008) Recent trends in the production, purification and application of lactic acid. Chem Biochem Eng Q 22(2):245-264

Wada M, Kato J, Chibata I (1980) Continuous production of ethanol using immobilized growing yeast cells. Eur J Appl Microbiol Biotechnol 10(4):275-287

Wahla AQ, lqbal S, Anwar S, Firdous S, Mueller JA (2019) Optimizing the metribuzin degrading potential of a novel bacterial consortium based on Taguchi design of experiment. J Hazard Mater 366:1-9

Walsh PK, Isdell FV, Noone SM, O'Donovan MG, Malone DM (1996) Growth patterns of Saccharomyces cerevisiae microcolonies in alginate and carrageenan gel particles: effect of physical and chemical properties of gels. Enzyme Microb Technol 18(5):366-372

Wang J, Huang J, Guo H, Jiang S, Zhang J, Ning Y, Fang M, Liu S (2020) Optimization of immobilization conditions for Lactobacillus penntosus cells. Bioprocess Biosyst Eng. https://doi.org/10.1007/s00449-020-02305-9

Wendhausen R, Fregonesi A, Moran PJ, Joekes I, Rodrigues JAR, Tonella E, Althoff K (2001) Continuous fermentation of sugar cane syrup using immobilized yeast cells. J Biosci Bioeng 91(1):48-52 
Won K, Kim S, Kim K-J, Park HW, Moon S-J (2005) Optimization of lipase entrapment in Ca-alginate gel beads. Process Biochem 40(6):2149-2154

Wu J, Wang JL, Li MH, Lin JP, Wei DZ (2010) Optimization of immobilization for selective oxidation of benzyl alcohol by Gluconobacter oxydans using response surface methodology. Bioresour Technol 101(23):8936-8941

Xu K, Xu P (2014) Efficient production of L-lactic acid using co-feeding strategy based on cane molasses/glucose carbon sources. Bioresour Technol 153:23-29

Zhan J, Jiang S, Pan L (2013) Immobilization of phospholipase A1 using a polyvinyl alcohol-alginate matrix and evaluation of the effects of immobilization. Braz J Chem Eng 30(4):721-728
Zhao Z, Xie X, Wang Z, Tao Y, Niu X, Huang X, Liu L, Li Z (2016) Immobilization of Lactobacillus rhamnosus in mesoporous silica-based material: an efficiency continuous cell-recycle fermentation system for lactic acid production. J Biosci Bioeng 121(6):645-651

Zhu GL, Hu YY, Wang QR (2009) Nitrogen removal performance of anaerobic ammonia oxidation co-culture immobilized in different gel carriers. Water Sci Technol 59(12):2379-2386

\section{Publisher's Note}

Springer Nature remains neutral with regard to jurisdictional claims in published maps and institutional affiliations.

\section{Submit your manuscript to a SpringerOpen ${ }^{\circ}$ journal and benefit from:}

- Convenient online submission

- Rigorous peer review

- Open access: articles freely available online

- High visibility within the field

- Retaining the copyright to your article

Submit your next manuscript at $\boldsymbol{\nabla}$ springeropen.com 